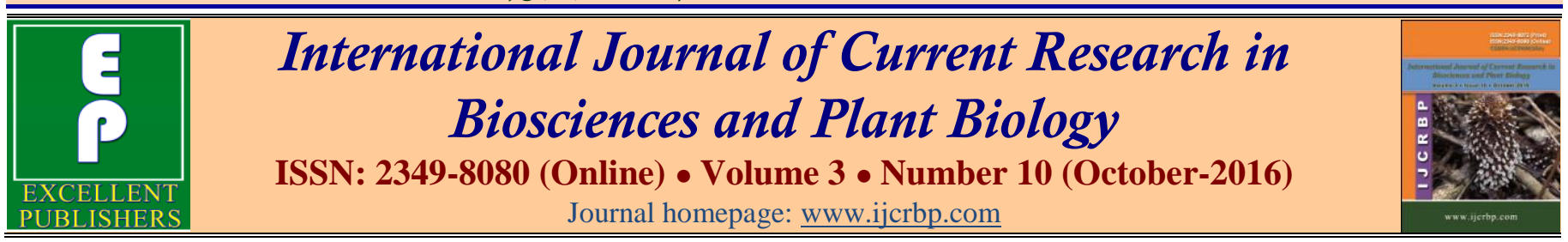

\title{
Yield Potential and Adaptability of Selected Food-grade Sorghum Hybrids to Mediterranean Conditions
}

\author{
Paola Pontieri ${ }^{*}$, Jacopo Troisi², Alessandro Bagnasco², Antonio Boffa', Mario Motto3, \\ Fabio Del Giudice4, Mitchell R. Tuinstra5, Alberto L. Chessa ${ }^{6}$, Graziano Pizzolante7, \\ Roberta Romano7, Pietro Alifano7 and Luigi Del Giudice1
}

\author{
${ }^{1}$ Istituto di Bioscienze e BioRisorse-UOS Portici-CNR c/o Dipartimento di Biologia, Sezione di Igiene, Napoli 80134, Italy \\ ${ }^{2}$ Theoreo srl - Spinf off of the University of Salerno - Via degli ulivi. 3 Montecorvino Pugliano (SA) Italy \\ 3 Fondazione per le Nuove Tecnologie per la Vita, Bergamo, Italy \\ 4 Bioteam Laboratory, via Girolamo Santacroce, Napoli 80129, Italy \\ 5 Purdue University, Department of Agronomy, West Lafayette, IN 47907, USA \\ ${ }^{6}$ Asesor Privado, Pueyrredón 971 (26oo), Venado Tuerto, Santa Fè, Argentina \\ 7 Dipartimento di Scienze e Tecnologie Biologiche e Ambientali, Università del Salento, Lecce 7310o, Italy
}

*Corresponding author.

\begin{abstract}
Sorghum has been grown as a food crop for many centuries in Africa and Asia and it is a cereal option for celiac patients. Due to its properties as a wheat-free food, interest is increasing in cultivating sorghum in Mediterranean countries. To evaluate the agronomic characteristics of growth in the Mediterranean area, six hybrids of sorghum (Sorghum bicolor L. Moench), representing different maturity classes, were selected and tested in experimental trials for 2 years in San Bartolomeo in Galdo (BN) hill, South Italy. The results showed moderate variation in adaptation of these hybrids as measured by differences in grain yields (4.60 to $7.30 \mathrm{t} \mathrm{ha}^{-1}$ ) and other phenomorphological traits. In particular, the hybrid SW6129W from Bolivia and the hybrid SASG05W from Argentina had grain yields higher than others tested in these trials. Our results demonstrated that selected food-grade hybrids from South America, have agronomic characteristics well-suited for cultivation in Mediterranean countries.

Abbreviations: EME, seedling emergence; FLO, flowering time; FP, fertile panicles; GFP, grain filling period; GYLD, grain yield; GYP, grain yield per panicle; IP, infertile panicles; LPE, length of panicle exertion; PH, plant height; PL, panicle length; PYLD, panicle yield.

\section{Article Info}

Accepted: 24 September 2016

Available Online: 06 October 2016

\section{Keywords}

Agronomic performance

Food-grade sorghum

Soil and climate conditions

Sorghum hybrid

Yield
\end{abstract}

\section{Introduction}

Sorghum (Sorghum bicolor L. Moench) is a crop that is widely grown for food and feed (Awika and Rooney, 2004; FAO, 2005). It is one of the main staples for many of the world's poorest people in the developing world, especially in the semi-arid tropics (Dendy, 1995; Anglani, 1998; Dicko et al., 2006; Pontieri and Del Giudice, 2016). Due to its tolerance to abiotic stresses, sorghum is valued as a climate-resilient crop (Dicko et al., 2006; Suhendro et al., 1998). United States is the largest producer and exporter of sorghum, accounting for $20 \%$ of world production, and almost $80 \%$ of global sorghum exports in 2001-2003 (USDA, 2003; Awika and Rooney, 2004).

Sorghum breeders have released numerous sorghum varieties and hybrid cultivars that exhibit improved 
performance in semi-arid and tropic environments (Tuinstra, 2008). Identification of varieties meeting specific food and industrial requirements is important for food security. In developing countries, particularly in West Africa, the demand for sorghum is increasing. This is due not only to the growing population, but also to country policies that promote its processing and industrial utilization (Dicko et al., 2006; Akintajo and Sedgo, 2001).

Genetic improvement and the expansion of production are two main ways of reaching higher production levels. The International Crop Research Institute for the SemiArid Tropics (ICRISAT) manages one of the largest collections of sorghum in the world with nearly 38,000 accessions. Expanded testing programs are required to evaluate the agronomic performance of these genotypes and to determine their value with respect to food and grain quality traits. More recently, molecular evidence indicated the absence of toxic gliadin-like peptides in sorghum, confirming that sorghum can be definitively considered safe for consumption by people with celiac disease (Pontieri et al., 2013).

Our research group is engaged in developing the cultivation of white, tan-plant, "food-grade" sorghum lines in South Italy (Del Giudice et al., 2008; Pontieri et al., 2010, 2011). Field trials were conducted in San Bartolomeo in Galdo (BN) in an area called Fortore, in Campania Region, South of Italy, were soils are predominantly clay loam, deep and with a good water holding capacity. It were evaluated the following agronomic traits: seedling emergence, flowering time, fertile panicles, grain filling period, grain yield, grain yield per panicle, infertile panicles, length of panicle exertion, plant height, panicle length and panicle yield, respectively. It is selected the best hybrid in yield for the right maturity which is a key point, since the other traits (drought tolerance, disease and insects tolerance, etc.) are going in the genetic pool.

Accordingly, the aim of the present study was to compare the agronomical performances of a set of white grain "food-grade" sorghum hybrids belonging to different maturity classes, with the perspective of their introduction in temperate Italian environmental area as a competitive crop.

\section{Materials and methods}

\section{Plant cultivars}

The sorghum cultivars and seed sources employed in this study are listed in Table 1. The F1 hybrids herein tested are considered food-grade sorghum genotypes with outstanding grain quality characteristics. The grain threshes free of the glumes and the caryopses are very round, a favourable trait in the food industry process. In particular, the hybrids have: a) white translucent grain colour; b) strong vitreous grain, easy and clean threshing; c) high test weight.

Table 1. List of sorghum hybrids.

\begin{tabular}{|c|c|c|}
\hline Hybrid Name & Source & Supplied by \\
\hline SW6129W & $\begin{array}{l}\text { Sem West s.r.l. } \\
\text { (Santa Cruz de la } \\
\text { Sierra, Bolivia) }\end{array}$ & Alberto Chessa \\
\hline SW6143W & $\begin{array}{l}\text { Sem West s.r.l. } \\
\text { (Santa Cruz de la } \\
\text { Sierra, Bolivia) }\end{array}$ & Alberto Chessa \\
\hline SASG05W & $\begin{array}{l}\text { Semillas Hibridas } \\
\text { Gaiman s.r.l } \\
\text { Venado Tuerto } \\
\text { (Santa Fe, Argentina) }\end{array}$ & Alberto Chessa \\
\hline SASG06W & $\begin{array}{l}\text { Semillas Hibridas } \\
\text { Gaiman s.r.l } \\
\text { Venado Tuerto } \\
\text { (Santa Fe, Argentina) }\end{array}$ & Alberto Chessa \\
\hline SASG07W & $\begin{array}{l}\text { Semillas Hibridas } \\
\text { Gaiman s.r.l } \\
\text { Venado Tuerto } \\
\text { (Santa Fe, Argentina) }\end{array}$ & Alberto Chessa \\
\hline SASG08W & $\begin{array}{l}\text { Semillas Hibridas } \\
\text { Gaiman s.r.l } \\
\text { Venado Tuerto } \\
\text { (Santa Fe, Argentina) }\end{array}$ & Alberto Chessa \\
\hline
\end{tabular}




\section{Soil and climatic conditions}

Soil and climate in the area Fortore in the Campania Region, South of Italy, where the food grade sorghum hybrid evaluations were conducted are: soils are predominantly clay loam, deep and with a good water holding capacity of about 3000 cubic meters per hectare to a depth of 0.60 meters. Provided that ensures the completion of the cultivation cycle of the sorghum plant in the absence of rain. The area of Fortore is localized to a variable altitude which starts from 230 to 900 meters above sea with variable slopes ranging up to $15 \%$. From a climatic point of view, the temperatures are relatively low in winter and easily drop below $0^{\circ} \mathrm{C}$, in spring temperatures remain around $10^{\circ} \mathrm{C}$ while in the spring end can easily exceed $16^{\circ} \mathrm{C}$. In the summer witnessing rise in temperature up to $30-35^{\circ} \mathrm{C}$ with night temperatures remained at $22-26^{\circ} \mathrm{C}$ with sporadic rains and storms (on average hovering around 100-150 millimetres of rain). With the reduction of hours of light at the end of the summer daytime temperatures drop below $30^{\circ} \mathrm{C}$ while the minimum drop below $20^{\circ} \mathrm{C}$. Usually in late summer start the first rains. Besides, regarding to both the soil and the South American climate from where originate the tested hybrids, they are actually planted, in Argentina, from $25^{\circ}$ to $40^{\circ}$ South Latitude $70^{\circ}$ to $53^{\circ}$ West Longitude, in all types of soils following the Direct Sowing system. Meanwhile in Bolivia, the referred hybrids are planted in the area of Santa Cruz de la Sierra $17.8^{\circ}$ South Latitude $53^{\circ}$ West Longitude in Direct Sowing.

\section{Experimental trials}

Field trials were conducted at San Bartolomeo in Galdo (BN), South Italy, on a clay-loam soil during summers 2012 and 2013. San Bartolomeo in Galdo is an inland area at the east of the Campania Region, about $530 \mathrm{~m}$ above the sea level. Six hybrids of sorghum (Table 1) were sown for the 2-years of testing around the second week of April (24 and 16, respectively). The experimental unit was formed by row plots $(2 \mathrm{~m} \times 5 \mathrm{~m})$, replicated 3 times, arranged in a randomized complete block design. Before sowing, a complex fertilizer $\left(\mathrm{NPK}=12-12-17\right.$ and 2-14 unit of $\mathrm{MgO}_{-} \mathrm{SO}_{3}$, respectively) was applied to the soil. Urea (N46\%) was applied at the stem elongation stage. An herbicide treatment of glyphosate $\left(4 \mathrm{~L} \mathrm{ha}^{-1}\right)$ was applied to the experimental field to eliminate weeds before planting. After planting, weeds were controlled by hand weeding as needed. Plants were grown without supplemental irrigation. In both years, the hybrids were harvested starting in late-August through mid-September.

The amount of rainfall received during the crop growing season ranged from 300 to $400 \mathrm{~mm}$ (April-September), mainly concentrated from the end of autumn (fall) to the beginning of spring. Climate data were measured in each year using a meteorological station located on a grassy area near the experimental field. Maximum and minimum temperatures and precipitation were collected on a monthly basis (Table 2). Soil characteristics of the site are reported in Table 3.

Table 2. Monthly rainfall, maximum and minimum temperature of growing season 2012 and 2013 recorded at San Bartolomeo in Galdo, BN, Italy.

\begin{tabular}{|c|c|c|c|c|c|c|c|c|}
\hline \multirow[b]{2}{*}{ Month } & \multicolumn{4}{|l|}{2012} & \multicolumn{4}{|l|}{2013} \\
\hline & T. $\min \left({ }^{\circ} \mathbf{C}\right)$ & T. $\max \left({ }^{\circ} \mathbf{C}\right)$ & $\begin{array}{l}\text { T. mean } \\
\left({ }^{\circ} \mathrm{C}\right)\end{array}$ & $\begin{array}{l}\text { Rainfall } \\
(\mathrm{mm})\end{array}$ & $\begin{array}{l}\text { T. min } \\
\left({ }^{\circ} \mathbf{C}\right)\end{array}$ & $\begin{array}{l}\text { T. max } \\
\left({ }^{\circ} \mathbf{C}\right)\end{array}$ & $\begin{array}{l}\text { T. mean } \\
\left({ }^{\circ} \mathrm{C}\right)\end{array}$ & $\begin{array}{l}\text { Rainfall } \\
(\mathrm{mm})\end{array}$ \\
\hline April & 6.6 & 13.6 & 10.1 & 89.8 & 8.8 & 15.5 & 12.1 & 45.8 \\
\hline May & 10.1 & 18.1 & 14.1 & 56.9 & 9.4 & 17.6 & 13.5 & 142.4 \\
\hline June & 14.9 & 24.4 & 19.6 & 4.6 & 14.3 & 22.9 & 18.6 & 68.0 \\
\hline July & 18.2 & 27.4 & 22.8 & 60.6 & 16.8 & 26.9 & 21.8 & 57.8 \\
\hline August & 17.9 & 28.1 & 23.0 & 40.4 & 13.8 & 22.6 & 18.2 & 38.8 \\
\hline September & 16.1 & 20.9 & 18.5 & 76.4 & 13.8 & 22.6 & 18.2 & 14.2 \\
\hline & 13.9 & 22.1 & 18.0 & 328.7 & 12.8 & 21.3 & 17.0 & 367.0 \\
\hline
\end{tabular}

\section{Evaluated traits}

Seedling emergence (EME) was scored as days required for $50 \%$ of the seeds to germinate. Flowering time (FLO) was recorded as the number of days from sowing to when $50 \%$ of plants had started flowering in a plot. Days to maturity was recorded as the number of days from planting to when seeds on $50 \%$ of the plants in a plot exhibited black layer on the lower third of the panicle. Grain filling period (GFP) was measured as the number of days between flowering date and physiological maturity.

At physiological maturity, data were collected for panicle yield (PYLD t ha ${ }^{-1}$ ), grain yield per panicle (GYP), and grain yield (GYLD t ha ${ }^{-1}$ ).Plant height (PH), length of panicle exertion (LPE) and panicle length (PL) 
were measured in randomly selected in ten plants during the milk stage when maximum height was achieved from the ground to the tip of the main panicle. PL $(\mathrm{cm})$ was recorded as length of the panicle from its base to tip; LPE $(\mathrm{cm})$ was measured as length between the base of the flag leaf and the base of the panicle; the PYLD (average of ten plants or panicles in the plot) was used to estimate the grain yield per panicle. In addition, the number of fertile (FP) and infertile panicles (IP) was also estimated. No bird damage was observed during the study period.

Table 3. Soil characteristics of the experimental area (San Bartolomeo in Galdo, BN, Italy).

\begin{tabular}{ll}
\hline Soil characteristic & 0-60 cm depth \\
\hline Clay $(\%)$ & 40.5 \\
Silt $(\%)$ & 19.3 \\
Sand $(\%)$ & 40.2 \\
$\mathrm{pH}$ & 8.3 \\
Exchangeable Ca $\left(\mathrm{g} \mathrm{kg}^{-1}\right)$ & 122 \\
Available $\mathrm{P}\left(\mathrm{mg} \mathrm{kg}^{-1}\right)$ & 12 \\
Exchangeable K $\left(\mathrm{meq}^{100 \mathrm{~g}^{-1}}\right)$ & 1.2 \\
Exchangeable Mg $\left(\mathrm{meq} \mathrm{100g}^{-1}\right)$ & 1.2 \\
Total Ca Carbonate $\left(\mathrm{g} \mathrm{kg}^{-1}\right)$ & 70 \\
Total N $\left(\mathrm{g} \mathrm{kg}^{-1}\right)$ & 1.0 \\
CSC $\left(\mathrm{meq} 100 \mathrm{gg}^{-1}\right)$ & 30 \\
Organic C $\left(\mathrm{g} \mathrm{kg}^{-1}\right)$ & 3.0 \\
\hline
\end{tabular}

Statistical analyses were conducted for each parameter by standard analysis of variance (ANOVA) in a factorial design with 2 years and 6 hybrids. Least significant difference (LSD) values were calculated at the 5\% probability level using Statistica Software (StatSoft, 2005).

\section{Results}

\section{Weather conditions and year effect}

The climate patterns during the sorghum growing seasons in 2012 and 2013 were generally average for the area. In fact, the total rainfall during the two growing seasons (April-September) was very similar ranging from 328.7 to $367.0 \mathrm{~mm}$ (Table 2). However, as is typical of the Mediterranean climate in this area, the distribution of rainfall was highly variable between the 2 years. The trial in 2012 was characterized by higher than average rainfall during the sowing period and during the final stages of grain development with a short period of drought in August. In 2013, slightly above average rainfall was observed during the early vegetative period followed by drought conditions at the end of the growing season. The morpho-agronomical traits for each hybrid are reported in Table 4. The favourable climatic conditions in 2013 supported good emergence and better hybrid grain yield than in $2012\left(6.00 \mathrm{t} \mathrm{ha}^{-1}\right.$ vs. $5.48 \mathrm{t} \mathrm{ha}^{-1}$ for 2013 and 2012, respectively).

\section{Hybrid performance}

The average plant height was $139.2 \mathrm{~cm}$ but individual hybrids varied significantly in plant height ranging from 121.0 to 158.5 for SASG08W and SASG05W, respectively (Table 4). Significant variation was also observed for panicle emergence ranging from 4.1 to 12.6 $\mathrm{cm}$ for SASG08W and SW6129W, respectively. All hybrids showed a high number of fertile panicles and relatively low number of infertile panicles. Although, if we consider the ratio between these values, the hybrid SASG08W registered the lowest value of 7.8 and SW6129W had the highest value of 43.7 indicating different reactions to the Mediterranean climate. The average panicle yield in the trials was $6.4 \mathrm{t} \mathrm{ha}^{-1}$ with individual hybrids varying from $2.95 \mathrm{t} \mathrm{ha}^{-1}$ for SASG08W to $8.20 \mathrm{t} \mathrm{ha}^{-1}$ for SASG05W. The grain yield for hybrid SW6143W at $4.7 \mathrm{t} \mathrm{ha}^{-1}$ was 1.5 times lower than that for SASG05W that produced $7.15 \mathrm{t} \mathrm{ha}^{-1}$. A similar trend was observed for grain yield per panicle with the SW6143W hybrid producing the lowest yields at $61.2 \mathrm{~g}$ panicle $^{-1}$ and SASG05W showing the highest value at $93.4 \mathrm{~g} \mathrm{panicle}^{-1}$ for this trait. The large variations in hybrid performance generally reflected differences in maturity. In this study, the hybrids have similar medium flowering times. Both in the 2012 and 2013 the average time from planting to anthesis was 67 days, but exhibited significant variation in GFP with SASG08W and the lowest one for SW6129W (35 and 45 days, respectively).

\section{ANOVA}

Statistical analyses indicated significant variation among the year (Y) and hybrids (Hy) main effects and their interactions (Table 4). All traits exhibited statistically significant variations with the exception of LPE for the year factor. The $\mathrm{Y} \times \mathrm{Hy}$ interaction was statistically significant, but this interaction was relatively small in terms of biological importance. For instance, regarding yield as the main attribute (but this is true for most of the traits considered) the mean square (MS) of genotypes was far greater than the MS for the interaction (Table 5). This must be interpreted as primary evidence that the interaction, although statistically significant, could not represent major changes in hybrid rankings for almost all the features. The year by hybrid interaction, although significant, did not display major crossover effects for the traits studied and thus was of minor importance. 
Table 4. Morpho-agronomical traits recorded at San Bartolomeo in Galdo, BN, Italy, during 2012 and 2013.

\begin{tabular}{|c|c|c|c|c|c|c|c|c|c|c|c|c|}
\hline & & 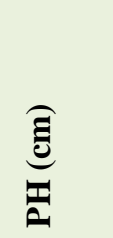 & $\underbrace{\widehat{E}}_{\text {ఏ }}$ & 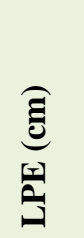 & $\vec{Z}$ & 空 & $\Leftrightarrow$ & 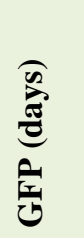 & 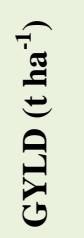 & 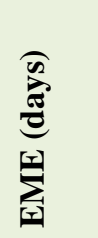 & $\begin{array}{l}\widehat{0} \\
\stackrel{0}{0} \\
0 \\
0 \\
0 \\
0\end{array}$ & 式 \\
\hline \multirow{4}{*}{ 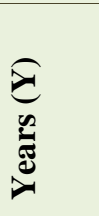 } & 2012 & 137.5 & 29.3 & 6.5 & 5.60 & 475.8 & 31.8 & 42 & 5.48 & 21.5 & 67.0 & 70.0 \\
\hline & 2013 & 140.9 & 26.2 & 8.6 & 7.25 & 482 & 34.8 & 39 & 6.00 & 21.0 & 67.0 & 76.9 \\
\hline & Mean & 139.2 & 27.7 & 7.5 & 6.4 & 478.9 & 33.3 & 40.5 & 5.7 & 21.25 & 67.0 & 73.4 \\
\hline & $L S D 0.05$ & 1.9 & 0.6 & 2.2 & 0.42 & 18 & 7 & 2.9 & 0.26 & 0.4 & 0.8 & 0.4 \\
\hline \multirow{8}{*}{ 串 } & SW6129W & 149.8 & 27.6 & 12.6 & 7.66 & 481 & 11 & 35 & 5.85 & 19.5 & 64 & 76.4 \\
\hline & SW6143W & 127.7 & 31.3 & 7.1 & 6.7 & 488.5 & 28 & 40 & 4.7 & 22 & 69 & 61.2 \\
\hline & SASG05W & 158.5 & 28.9 & 8.4 & 8.2 & 458.5 & 41.5 & 41 & 7.15 & 19 & 66 & 93.4 \\
\hline & SASG06W & 130.2 & 25.4 & 4.4 & 6.57 & 472 & 26.5 & 44 & 5.6 & 22 & 68 & 73.1 \\
\hline & SASG07W & 148.1 & 30.4 & 8.6 & 6.45 & 478 & 29.5 & 44 & 5.7 & 21.5 & 68 & 72.2 \\
\hline & SASG08W & 121.0 & 22.7 & 4.1 & 2.95 & 495.5 & 63.5 & 45 & 5.45 & 23.5 & 67 & 64.3 \\
\hline & Mean & 139.2 & 27.7 & 7.5 & 6.4 & 478.9 & 33.3 & 41.5 & 5.7 & 21.25 & 67.0 & 73.4 \\
\hline & LSD 0.05 & 3.1 & 2.2 & 1.6 & 0.43 & 42 & 17 & 4.1 & 0.52 & 1.3 & 1.2 & 1.2 \\
\hline \multirow{8}{*}{ 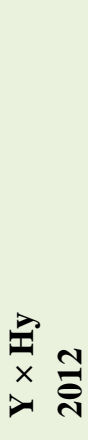 } & SW6129W & 145.6 & 30.0 & 10.4 & 6.42 & 484 & 10 & 36 & 5.30 & 20 & 64 & 68.6 \\
\hline & SW6143W & 124.3 & 32.0 & 5.5 & 6.83 & 487 & 28 & 44 & 4.60 & 23 & 68 & 62.3 \\
\hline & SASG05W & 161.6 & 33.6 & 7.7 & 7.20 & 449 & 35 & 36 & 7.00 & 19 & 67 & 92.2 \\
\hline & SASG06W & 126.6 & 26.3 & 4.3 & 6.30 & 465 & 25 & 38 & 5.40 & 22 & 68 & 72.1 \\
\hline & SASG07W & 141.6 & 31.3 & 7.7 & 4.25 & 475 & 28 & 36 & 5.20 & 21 & 66 & 66.2 \\
\hline & SASG08W & 125.3 & 22.7 & 3.6 & 2.60 & 495 & 65 & 47 & 5.40 & 24 & 69 & 58.6 \\
\hline & Mean & 137.5 & 29.3 & 6.5 & 5.60 & 475.8 & 31.8 & 39.5 & 5.48 & 21.5 & 67.0 & 70.0 \\
\hline & LSD 0.05 & 5.5 & 2.0 & 4.4 & 0.64 & 51.4 & 21.5 & 4.3 & 0.87 & 1.1 & 1.7 & 1.2 \\
\hline \multirow{8}{*}{$\underset{x}{\stackrel{2}{*}}$} & SW6129W & 154.0 & 25.2 & 14.8 & 8.90 & 478 & 12 & 34 & 6.40 & 19 & 64 & 84.2 \\
\hline & SW6143W & 131.1 & 30.7 & 8.7 & 6.60 & 490 & 28 & 40 & 4.80 & 21 & 70 & 60.1 \\
\hline & SASG05W & 155.4 & 24.3 & 9.1 & 9.20 & 468 & 48 & 35 & 7.30 & 19 & 65 & 94.6 \\
\hline & SASG06W & 133.8 & 24.5 & 4.5 & 6.85 & 479 & 28 & 39 & 5.80 & 22 & 68 & 74.2 \\
\hline & SASG07W & 154.6 & 29.6 & 9.6 & 8.65 & 481 & 31 & 42 & 6.20 & 22 & 70 & 78.3 \\
\hline & SASG08W & 116.7 & 22.8 & 4.7 & 3.30 & 496 & 62 & 44 & 5.50 & 23 & 65 & 70.1 \\
\hline & Mean & 140.9 & 26.2 & 8.6 & 7.25 & 482 & 34.8 & 39 & 6.00 & 21.0 & 67.0 & 76.9 \\
\hline & $L S D 0.05$ & 4.3 & 1.9 & 4.2 & 0.44 & 50.6 & 19.5 & 3.6 & 0.87 & 1.4 & 2.2 & 1.4 \\
\hline
\end{tabular}

*Means with the same letter are not significantly different $(p \leq 0.05)$ according to Tukey's test.

PH, plant height; PL, panicle length; LPE, length of peduncle exertion; PYLD, panicle yield; FP, number of fertile panicle; IP, number of infertile panicle; GFP, grain filling period; GYLD, grain yield; EME, number of days from sowing to seedling emergence; FLO, number of days from sowing to 50\% of flowering plant; GYP, grain yield per panicle. Note: Least significant difference (LSD) test was used for comparing the means at $0.05 \%$ probability level. 
Table 5. Mean sum of squares (ANOVA) of sorghum hybrids traits recorded at San Bartolomeo in Galdo, BN, Italy, during 2012 and 2013.

\begin{tabular}{|c|c|c|c|c|c|c|c|c|c|c|c|c|}
\hline Source of variation & DF & PH & PL & LPE & PYLD & FP & IP & GFP & GYLD & EME & FLO & GYP \\
\hline Replication & 2 & 10.4 & 1.4 & 0.8 & 0.6 & 41.5 & 3.1 & 6.7 & 0.6 & 18.4 & 6.1 & 4.3 \\
\hline Hybrids & 5 & 1.25 & 9.97 & 7.55 & 10.02 & 256.78 & 30.74 & 25.06 & 7.58 & 11.28 & 95.91 & 43.21 \\
\hline Years & 1 & 3.49 & 25.7 & 20.9 & 12.56 & 261.03 & 32.75 & 28.23 & 307.5 & 16.26 & 152.03 & 24.52 \\
\hline $\mathrm{H} \times \mathrm{Y}$ & 5 & 0.91 & 1.57 & 0.86 & 1.04 & 2.67 & 3.08 & 1.9 & 3.56 & 5.21 & 12.83 & 11.65 \\
\hline Error & 30 & 0.07 & 1.02 & 0.05 & 0.71 & 1.81 & 1.97 & 0.96 & 1.05 & 2.03 & 3.24 & 1.56 \\
\hline Total & 36 & & & & & & & & & & & \\
\hline
\end{tabular}

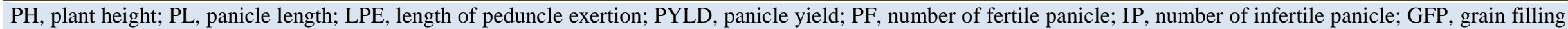

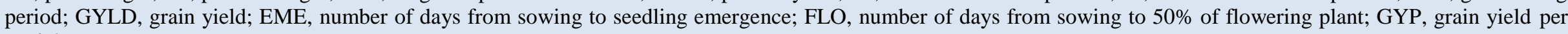
panicle.

Table 6. Correlation coefficients of sorghum hybrids traits recorded at San Bartolomeo in Galdo, BN, Italy during 2012 and 2013.

\begin{tabular}{|c|c|c|c|c|c|c|c|c|c|c|c|}
\hline & $\mathbf{P H}$ & PL & LPE & PYLD & PF & IP & GFP & GYLD & EME & FLO & GYP \\
\hline PH & 1.00 & & & & & & & & & & \\
\hline PL & 0.36 & 1.00 & & & & & & & & & \\
\hline LPE & $0.73 * *$ & 0.26 & 1.00 & & & & & & & & \\
\hline PYLD & $0.72 * * *$ & 0.29 & $0.66 * * *$ & 1.00 & & & & & & & \\
\hline PF & -0.67 & -0.36 & -0.17 & -0.52 & 1.00 & & & & & & \\
\hline PI & -0.39 & -0.51 & -0.60 & -0.58 & 0.28 & 1.00 & & & & & \\
\hline GFP & -0.70 & -0.40 & -0.69 & -0.75 & $0.63 * *$ & $0.74 *$ & 1.00 & & & & \\
\hline GYLD & $0.77 *$ & -0.16 & 0.37 & $0.54 * * *$ & -0.66 & 0.12 & -0.43 & 1.00 & & & \\
\hline EME & -0.86 & -0.31 & -0.77 & -0.72 & $0.66^{*}$ & 0.50 & $0.88 * *$ & -0.67 & 1.00 & & \\
\hline FLO & -0.34 & 0.20 & -0.50 & -0.13 & 0.16 & 0.20 & 0.55 & -0.38 & $0.57 *$ & 1.00 & \\
\hline GYP & $0.80 * *$ & -0.02 & 0.44 & $0.68 *$ & -0.76 & -0.08 & -0.62 & $0.96 * *$ & -0.77 & -0.43 & 1.00 \\
\hline
\end{tabular}

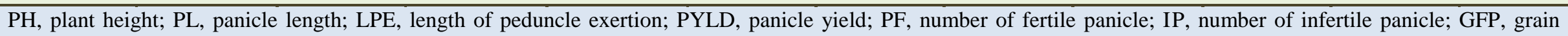

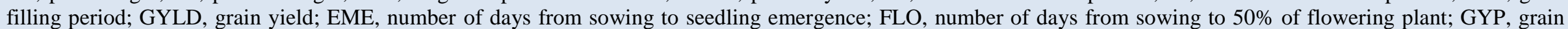
yield per panicle. $*, * *, * * *$ Significant correlation at $* p<0.05, * * p<0.01$ and $* * * p<0.001$. 


\section{Correlations}

The correlations among the traits for hybrids selected in this work are presented in Table 6. Height of hybrids $(\mathrm{PH})$ showed a significant positive correlation with panicle yield performance (PYLD) $\left(\mathrm{r}^{2}=0.72, p<0.001\right)$ and panicle yield (PYLD) showed approximately the same correlation with the length of peduncle exertion (LPE) $\left(\mathrm{r}^{2}=0.66, p<0.001\right)$. As expected, a positive correlation was found between grain yield (GYLD) and panicle yield (PYLD) $\left(\mathrm{r}^{2}=0.54, p<0.001\right)$, height of hybrids $(\mathrm{PH})\left(\mathrm{r}^{2}=0.77, p<0.05\right)$ and grain yield for panicle (GYP) $\left(\mathrm{r}^{2}=0.96, p<0.01\right)$. There is a strong positive correlation between the numbers of days from sowing to seedling emergence (EME) and numbers of fertile panicle $(\mathrm{PF})\left(\mathrm{r}^{2}=0.66, p<0.05\right)$ and grain filling period(GFP) $\left(\mathrm{r}^{2}=0.88, p<0.01\right)$. The numbers of days from sowing to seedling emergence (EME) showed a strong negative correlation with grain yield (GYLD) $\left(\mathrm{r}^{2}=-0.67\right)$ and plant height $(\mathrm{PH}) \quad\left(\mathrm{r}^{2}=-0.86\right)$. The correlations among the observed parameters were also investigated through a biplot from Principal Component Analysis (PCA) (Fig. 1). The yield parameters (GYLD, GYP, PYLD) have the same direction, this confirms the good positive correlation among these parameters. These parameters show also a negative and good correlation with panicle length and the number of fertile panicles.

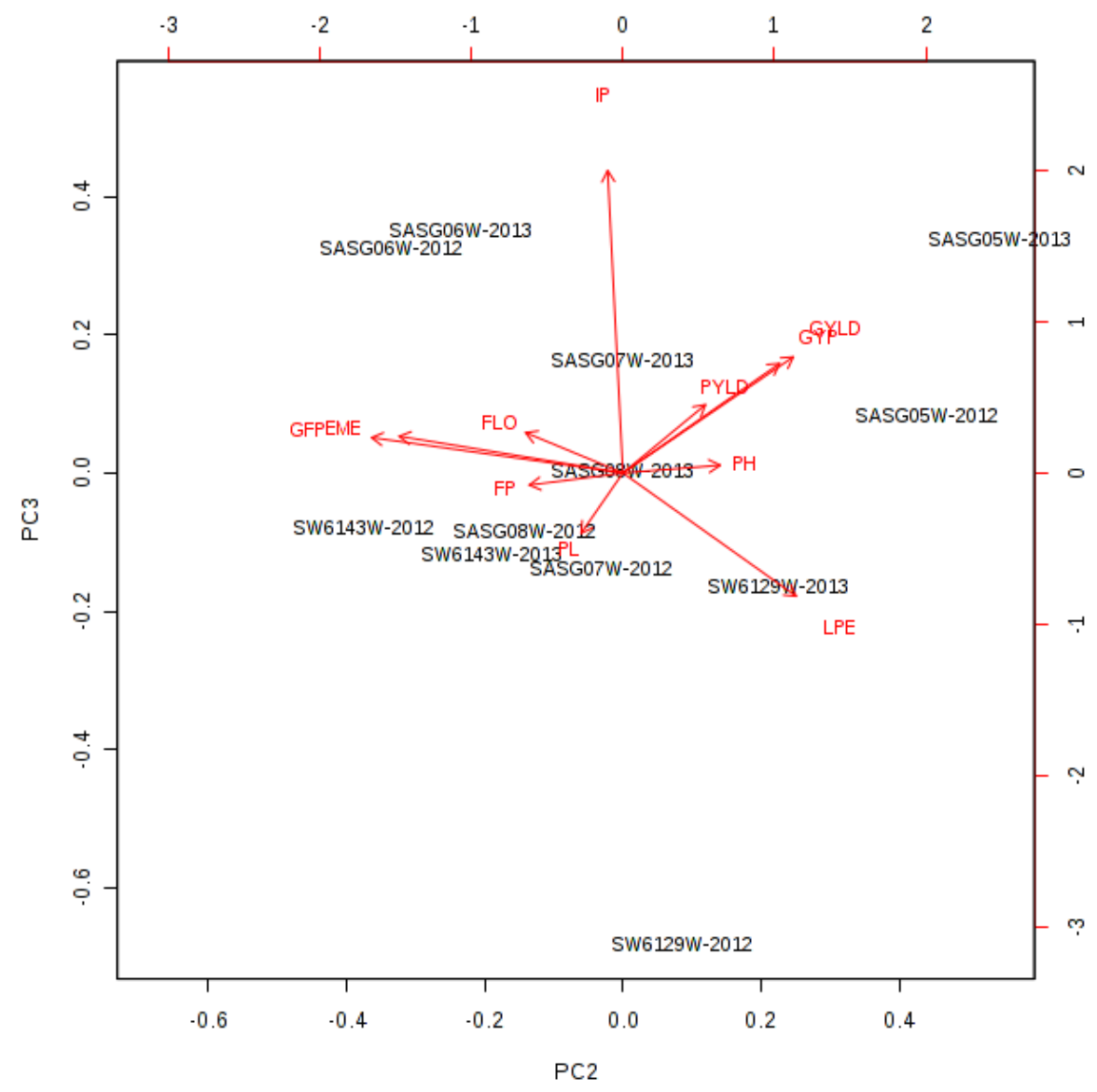

Fig. 1: Principal Component Analysis Biplot. PH, plant height; PL, panicle length; LPE, length of peduncle exertion; PYLD, panicle yield; FP, number of fertile panicle; IP, number of infertile panicle; GFP, grain filling period; GYLD, grain yield; EME, number of days from sowing to seedling emergence; FLO, number of days from sowing to $50 \%$ of flowering plant; GYP, grain yield per panicle.

\section{Discussion}

Sorghum is an ancient grain that has been used as a human food staple for thousands of years. Recent research is discovering many new potential health benefits from sorghum, such as high anti-oxidant levels, improved cholesterol profile, and as a source of safe food for persons with celiac disease. As sorghum is a drought- 
resistant and heat-tolerant grain, it can often be grown in areas where other cereals cannot. This may become more important as the world population continues to rise and water shortages are projected for many agricultural regions. The production of high-quality sorghum foods is an area of needed research that takes advantage of the health benefits of sorghum.

The primary scope of the current experiments was the investigation of the adaptability of white food-grade sorghum hybrids selected from South America to grow in Mediterranean environments. Almost all studies in Italy that have investigated the agronomic or quality traits of sorghum refer to forage (Dolciotti et al., 1998; Colombo et al., 2007), biomass (Belletti et al., 1991), or sweet sorghum (Monti and Venturi, 2003).The wide adaptability of white food-grade sorghum hybrids of both USA and Africa origins in Italian regions has been recently highlighted (Pontieri et al., 2010, 2011).

White grain sorghum is an interesting crop for the southern regions of the EU. High quality human food products can be made from sorghum flour-products such as breads (Schober et al., 2005), sorghum tortillas (Choto et al., 1985), snack foods (Serna-Saldivar et al., 1988), cookies (Badi and Hoseney, 1976), and flatbreads (Morad et al., 1984). In addition, white grain sorghum may provide a good basis for gluten-free breads and other baked products such as pasta, cookies, and snacks since direct testing has been conducted on its safety for celiac patients (Ciacci et al., 2007; Del Giudice et al., 2008). The present study represents one of the first attempts to evaluate the possibility of growing foodgrade white sorghum hybrids from South America in Italy. To this purpose, six hybrids characterized by different morpho-phenological traits were compared in order to identify those capable of fully expressing their maximum yield potential in the environmental conditions of South Italy.

Sorghum grown under rain-fed conditions is usually affected by drought stress at different stages of growth and development, resulting in a negative effect on yield. Moisture stress at boot stage may prevent the head from exerting completely from the flag leaf sheath, which may cause harvesting difficulties. The crop will respond favourably to irrigation at this stage. Following the boot stage, the peduncle grows rapidly extending the head through the flag leaf sheath. Prasad et al. (2008) documented that sorghum was most sensitive to heat stress about 10 days before and during pollination, causing maximum reductions in seed set and yield. Our findings confirm these previous data: both late-flowering hybrids SW6129W and SASG07W were exposed to a short period of high-temperature stress (8-12 and 22-27 July with maximum temperature $>30^{\circ} \mathrm{C}$ during 2012 and 2013, respectively) during reproductive development. Nevertheless, a few highly productive hybrids were identified. In particular, the high yield levels recorded from early-flowering hybrids underline the possibility of cultivating this crop in the areas of Centre and South of Italy, providing a valid crop alternative to durum wheat monoculture for farmers.

The hybrids in this trial exhibited variation in $\mathrm{PH}$ ranging from $121.0 \mathrm{~cm}$ for SASG08W to $158.5 \mathrm{~cm}$ for SASG05W (Table 4). Significant variation was also observed for LPE ranging from $4.1 \mathrm{~cm}$ to $12.6 \mathrm{~cm}$ for SASG08W and SW6129W, respectively. All hybrids showed a high level of fertile panicles (FP) and relatively low number of infertile panicles (IP), although, if we consider the ratio between these values, the hybrid SASG08W registered lowest score at 7.8 and SW6129W exhibited the highest score at 43.7. The GYLD recorded for the hybrid SW6143W (4.7 $\left.\mathrm{tha}^{-1}\right)$ was 1.5 times lower than SASG05W (7.15 $\left.\mathrm{t} \mathrm{ha}^{-1}\right)$. A similar trend was observed for GYP, with the SW6143W hybrid performing poorest $(61.2 \mathrm{~g})$, and SASG05W showing the highest value $(93.4 \mathrm{~g})$ for this trait.

From the latter data it can be deduced a yield advantages of hybrid SASG05W with yield over than $7.0 \mathrm{t} \mathrm{ha}^{-1}$ and a yield disadvantage of hybrid SW6143W with yield of 4.7 $\mathrm{t}$ ha ${ }^{-1}$ compared to the yields of the other four hybrids in the study. Based on yield performance, SASG05Wcould be recommended to be grown in Southern Italy to promote white grain sorghum cultivation and production of high quality human food products. Hybrid sorghum examined in the present work are the species that produce food grade white colour grain are intended for human consumption. The flour produced from the food grade sorghum grain is white in colour and is suitable for the production of food for humans. This flour allows to produce bakery foods for humans such as cookies, bread, pasta and other. The quality of the food grade sorghum flour test consists in evaluating the attractiveness and palatability of food produced. In the present work, the flour quality testing produced by the grain of the six food grade sorghum hybrids coming from South America was evaluated by the quality of the cookies which they have produced (data not shown) according to the recent publication (Pontieri and Del Giudice, 2016). It is also important to stress that the climatic conditions of the experimental site were characterized by comparable 
amount of rainfall and temperatures during the six months of the entire crop growing cycle for both years making it possible to well identify the most suitable hybrid to grow and with high yields in South Italy.

\section{Conclusion}

In conclusion, our data indicate that it is possible to grow sorghum hybrids from South America in South Italy regions. This in agreement with previous results from field trials reported by us in Italy, concerning sorghum hybrids from USA and Africa (Pontieri et al., 2010, 2011). In the future, the capacity of organizing in Italy a selection program of white food-grade sorghums could improve the agricultural economy in this country and perhaps in the whole of Europe.

\section{Conflict of interest statement}

Authors declare that they have no conflict of interest.

\section{Acknowledgement}

We thank Fulvia Stanzione for statistical analysis support and Mariarosaria Aletta for bibliographic support. The technical assistance of Concetta Porzio is acknowledged. The research was supported by both MIURPON03PE_00060_2, Decreto di Concessione del 27/06/2014, Progetto 2 "Progettazione, sviluppo e produzione di cibi funzionali e/o arricchiti", (OR4: Farine funzionali e prodotti da forno per celiaci ed intolleranti al glutine) to P. Pontieri and Regione Campania special grant (P.S.R. Campania 2007-2013, Misura 41 sottomisura 411, Misura 124 - Provvedimento di concessione n.ro 29 del 03.06.2014 - Progetto FAASACS) to L. Del Giudice. P. Pontieri was supported by a postdoctoral grant from the Istituto Banco di Napoli, Fondazione.

\section{References}

Akintayo, I., Sedgo, J., 2001. Production, utilization, and marketing of sorghum in Southern Africa region. In: Towards sustainable sorghum production and utilization in West and Central Africa: proceedings of a Technical Workshop of the West and Central Africa Sorghum Research Network (Eds.: Akintayo, I., Sedgo, J.,). 19-22 April 1999, Lomé, Togo. p. 162.

Anglani, C., 1998. Sorghum for human food: a review. Plant Foods Hum. Nutr.52, 85-89.

Awika, J.M., Rooney, L.W., 2004. Sorghum phytochemicals and their potential aspects on human health. Phytochemistry. 65, 1199-1221.
Badi, S.M., Hoseney, R.C., 1976. Use of sorghum and pearl millet flours in cookies. Cereal Chem. 53, 733-738.

Belletti, A., Petrini, C.,Minguzzi, A., Landini, V.,Piazza, C.,Salamini, F.,1991.Yield potential and adaptability to Italian conditions of sweet sorghum as biomass crop for energy production. Maydica. 36, 283-291.

Choto, C.E.,Morad, M.M., Rooney, L.W., 1985. The quality of tortillas containing whole sorghum and pearled sorghum alone and blended with yellow maize. Cereal Chem. 62, 51-55.

Ciacci, C., Maiuri, L., Caporaso, N., Bucci, C., Del Giudice, L., Massardo, D.R., Pontieri, P., Di Fonzo, N., Bean, S.R., Ioerger, B.,Londei, M.,2007, Celiac disease: in vitro and in vivo safety and palatability of wheat-free sorghum food products. Clin. Nutr. 26, 799-805.

Colombo, D.,Crovetto, G.M., Colombini, S., Galassi, G.,Rapetti, L.,2007. Nutritive value of different hybrids of sorghum forage determined in vitro. Ital. J. Anim. Sci. 6, 289-291.

Del Giudice, F., Massardo, D.R., Pontieri, P., Maddaluno, L., De Vita, P., Fares, C.,Ciacci, C.,Del Giudice, L., 2008. Development of a sorghum chain in the Italian Campania Region: from the field to the celiac patient's table. J. Plant Interact. 3, 49-55.

Dendy, D.A.V., 1995. Sorghum and the millets: production and importance. In: Sorghum and millets: chemistry and technology (Ed.: Dendy, D.A.V.). St. Paul, MN: American Association of Cereal Chemists. pp. 11-26.

Dicko, M.H., Gruppen, H., Traoré, A.S., Voragen, A.G.J.,van Barkel, W.J.H., 2006. Sorghum grain as human food in Africa: relevance of content of starch and amylase activities. Afr. J. Biotechnol. 5, 384-395.

Dolciotti, I., Mambelli, S., Grandi, S.,Venturi, G.,1998. Comparison of two sorghum genotypes for sugar and fiber production. Ind. Crop Prod. 7, 265-272.

FAO, Food and Agricultural Organization. 1995. Sorghum and millet in human nutrition. FAO Food and Nutrition Series No. 27. ISBN 92-5-103381-1. Available from: www.fao.org/DOCREP/T0818E00.htm\#Contents.

Monti, A.,Venturi, G., 2003. Comparison of the energy performance of fiber sorghum, sweet sorghum and wheat monocultures in northern Italy. Eur. J. Agron. 19, 35-43.

Morad, M.M., Doherty, C.A.,Rooney, L.W., 1984. Effect of sorghum variety on baking properties of US conventional bread, Egyptian pita "Balady" bread and cookies. J. Food Sci. 49, 1070-1074.

Pontieri,P.,Del Giudice, L., 2016. Sorghum: A novel and healthy food. In: The Encyclopedia of Food and Health (Eds.: Caballero, B., Finglas, P., Toldrà, F.). Oxford, UK. pp.33-42.

Pontieri, P., Mamone, G., De Caro, S., Tuinstra, M.R., Roemer, E., Okot, J., De Vita, P., Ficco, D.B.M., Alifano, P., Pignone, D., Massardo, D.R., Del Giudice, L., 2013. Sorghum, a healthy and gluten-free food for celiac patients as demonstrated by genome, biochemical and immunochemical analyses. J. Agric. Food Chem. 61, 2565-2571. 
Pontieri, P., Di Fiore, R., Troisi, J., Bean, S.R., Roemer, E., Okot, J., Alifano, P., Pignone, D., Del Giudice, L., Massardo, D.R., 2011. Chemical composition and fatty acid content of white food sorghums grown in different environments. Maydica. 56, 1-7.

Pontieri, P., Di Maro, A., Tamburino, R., De Stefano, M., Tilley, M., Bean, S.R., Roemer, E., De Vita, P., Alifano, P., Del Giudice, L., Massardo, D.R., 2010. Chemical composition of selected food-grade sorghum varieties grown under typical mediterranean conditions. Maydica. 55, 139-143.

Prasad, P.V.V., Pisipati, S.R., Mutava, R.N., Tuinstra, M.R., 2008. Sensitivity of grain sorghum to high temperature stress during re productive development. Crop Sci. 48, 1911-1917.

Schober, T.J., Messerschmidt, M., Bean, S.R., Park, S.H., Arendt, E.K., 2005. Gluten-free bread from sorghum: quality differences among hybrids. Cereal Chem. 82, 394404.

Serna-Saldivar, S.O., Tellez-Giron, A., Rooney, L.W., 1988. Production of tortilla chips from sorghum and maize. J. Cereal Sci. 8, 275-284.

StatSoft Inc., 2005. STATISTICA release 5 user's manual. StatSoft Inc., Tulsa, OK.

Suhendro, E.L., McDonough, C.M., Rooney, L.W., Waniska, R.D., Yetneberk, S., 1998. Effects of processing conditions and sorghum cultivar on alkaline-processed snacks. Cereal Chem. 75, 187-193.

Tuinstra, M.R., 2008. Food-grade sorghum varieties and production considerations: a review. J. Plant Interact. 3, 69-72.

USDA, United States Department of Agriculture-Foreign Agriculture Division. 2003 data. Available from: www.fas.usda.gov/psd.

\section{How to cite this article:}

Pontieri, P., Troisi, J., Bagnasco, A., Boffa, A., Motto, M., Del Giudice, F., Tuinstra, M. R., Chessa, A. L., Pizzolante, G., Romano, R., Alifano., P., Del Giudice, L., 2016. Yield potential and adaptability of selected foodgrade sorghum hybrids to Mediterranean conditions. Int. J. Curr. Res. Biosci. Plant Biol. 3(10), 118-127. doi: http://dx.doi.org/10.20546/ijcrbp.2016.310.014 